\title{
The Emerging Role of Epigenetics in the Regulation of Female Puberty
}

\author{
Alejandro Lomniczi • Sergio R. Ojeda
}

Division of Neuroscience, Oregon National Primate Research Center/Oregon Health and Science University, Beaverton, Oreg., USA

\begin{abstract}
In recent years the pace of discovering the molecular and genetic underpinnings of the pubertal process has accelerated considerably. Genes required for human puberty to occur have been identified and evidence has been provided suggesting that the initiation of puberty requires coordinated changes in the output of a multiplicity of genes organized into functional networks. Recent evidence suggests that a dual mechanism of epigenetic regulation affecting the transcriptional activity of neurons involved in stimulating gonadotropin-releasing hormone release plays a fundamental role in the timing of puberty. The Polycomb group $(\mathrm{PcG})$ of transcriptional silencers appears to be a major component of the repressive arm of this mechanism. PcG proteins prevent the premature initiation of female puberty by silencing the Kiss 1 gene in kisspeptin neurons of the arcuate nucleus (ARC) of the hypothalamus. Because the abundance of histone marks either catalyzed by - or associated with - the Trithorax group (TrxG) of transcriptional activators increases at the time when PcG control subsides, it appears that the TrxG complex is the counteracting partner of PcG-mediated gene silencing. In this chapter, we discuss the concept that a switch from epigenetic repression to activation within ARC kisspeptin neurons is a core mechanism underlying the initiation of female puberty.
\end{abstract}

(c) 2016 S. Karger AG, Basel

The timing of puberty is determined by interactions that occur between genetic and environmental factors. From a purely neuroendocrine standpoint, puberty begins when pulsatile gonadotropin-releasing hormone $(\mathrm{GnRH})$ release from neurosecretory neurons of the hypothalamus increases in a diurnal fashion and for a sustained period of time, driving the pituitary gland to release more $\mathrm{LH}$, also in a pulsatile fashion and with a diurnal periodicity. The pubertal increase in $\mathrm{GnRH}$ secretion does not appear to be driven by intrinsic changes in GnRH neuronal activity; instead, it is brought about by changes in transsynaptic and glial inputs to $\mathrm{GnRH}$ neurons. These changes consist of a reduction in inhibitory transsynaptic inputs coupled with an increase in transsynaptic and glial excitatory inputs to the GnRH neuronal network [reviewed in 1]. 
While it has been accepted for many years that the time of puberty has a strong genetic component, very recently epigenetics has been implicated as an important regulatory mechanism underlying not only the developmental process by which $\mathrm{GnRH}$ release is first kept in check before puberty, but also the increase in GnRH secretion that brings about the pubertal process. According to this emerging concept, an important target of epigenetic regulation is the transcriptional machinery of neurons involved in stimulating GnRH release. In this article we will briefly consider the hormonal changes associated with the advent of puberty and the role that excitatory transsynaptic inputs have in this process. Thereafter, we will discuss the nascent body of evidence supporting the existence of an epigenetic mode of regulation residing at the heart of the neuroendocrine process that controls puberty.

\section{The Hormonal Changes of Puberty and Its Underlying Neuroendocrine Regulatory Mechanisms}

In 1972, Boyar et al. [2] introduced the now widely accepted concept that an increase in pulsatile LH release is the first endocrine manifestation of the initiation of puberty. This study demonstrated that the amplitude of LH pulses detected in the bloodstream of peripubertal girls increases shortly after the initiation of sleep during early puberty, before any somatic manifestation becomes apparent and in the absence of changes in circulating ovarian steroid levels. In rodents, the increase in LH pulsatility is also ovary independent, occurs in the afternoon and is first observed by the end of the juvenile period $[3,4]$. As a consequence of the elevated plasma LH levels, gonadal output of sex steroids increases, and this change leads to the development of secondary sexual characteristics. In females, there is another event that needs to occur for puberty to be completed: the first preovulatory surge of gonadotropins, which occurs upon maturation of the central mechanism of estrogen-positive feedback. It is also clear that the pubertal change in pulsatile LH output is driven by an increase in pulsatile release of $\mathrm{GnRH}$ from the hypothalamus [reviewed in 5]. Because GnRH neurons are able to produce and release $\mathrm{GnRH}$ long before puberty, it has been concluded that they are neither ultimately responsible for the initiation of puberty nor constitute a significant obstacle for the pubertal process to be initiated earlier [5].

A primary transsynaptic mechanism underlying pulsatile $\mathrm{GnRH}$ release is believed to be the synchronized activity of a subset of arcuate nucleus (ARC) neurons termed KNDy neurons $[6,7]$ because in rodents and sheep they produce kisspeptin, NKB and dynorphin $[6,8]$. In humans there is a large population of kisspeptin-containing neurons in the infundibular nucleus (equivalent to the ARC in rodents), but also extending into the infundibular stalk $[9,10]$. In postmenopausal women, about $70 \%$ of these neurons also contain $\mathrm{NKB}$, but this colocalization is substantially lower (36\%) in young adult males $[9,10]$. Attempts to identify dynorphin in infundibular kisspeptin neurons of young human males have been unsuccessful, suggesting that infundibular 
kisspeptin neurons in humans either do not contain dynorphin or that dynorphin levels in young males are too low to be detected [10]. Studies in rodents and sheep have shown that KNDy neurons release NKB, which acts on other KNDy neurons via specific receptors to stimulate kisspeptin release $[6,8]$. NKB and kisspeptin are released periodically, and this rhythmic behavior appears to be primarily determined by an inhibitory, recurrent effect of dynorphin on NKB release $[6,8]$.

Direct evidence for a role of ARC kisspeptin neurons (henceforth referred to as KNDy neurons) in the genesis of pulsatile LH release was recently provided [11]. Although there is a population of kisspeptin neurons located in the anteroventral periventricular nucleus (AVPV) of rodents [reviewed in 12], they do not contribute to the control of pulsatile GnRH release. Instead, AVPV neurons are required for the preovulatory surge of gonadotropins [12]. Accordingly, they do not appear to be involved in the initiation of female puberty because the gonadotropin surge occurs only after the pubertal process is well underway. In humans, there is also a rostral population of kisspeptin neurons located in the rostral periventricular area of the third ventricle and extending to the ventral periventricular and paraventricular nucleus $[9,10]$. The contribution of these neurons to the preovulatory surge of gonadotropins in humans remains to be established.

For years the initiation of puberty has been postulated to result from removal of a central 'brake' [13]. According to this concept, the secretory activity of GnRH neurons is under predominant transsynaptic inhibitory control during the prepubertal period. At puberty this inhibition would be lifted, resulting in the unleashing of GnRH release [reviewed in 5]. Another view proposed more than 20 years ago is that puberty cannot occur unless there is an increase of excitatory inputs to the GnRH network [14]. This latter concept was strongly supported by the demonstration that activation of kisspeptin neurons, which provide a significant fraction of the stimulatory inputs controlling GnRH neurons [reviewed in 12], is essential for puberty to occur [15, 16]. Based on these and other observations it is now believed that a concomitant decrease in inhibitory inputs and an increase in excitatory neurotransmission are the essential cell-cell counterbalancing mechanisms underlying the initiation of the pubertal process [reviewed in 5].

Notwithstanding the potential importance of this transsynaptic regulatory mechanism, evidence was recently presented suggesting the existence of a molecular switch that controls the timing of puberty by epigenetically regulating the transcriptional activity of neurons involved in stimulating $\mathrm{GnRH}$ release.

\section{Modes of Epigenetic Regulation}

There are three mechanisms of epigenetic control: (1) chemical modifications of the DNA via DNA methylation and hydroxymethylation, (2) posttranslational modifications (PTMs) of the four histones that provide the protein component of nucleosomes, the core unit of chromatin, and (3) noncoding RNAs, which carry epigenetic information as either microRNAs (miRNAs) or as long intergenic noncoding RNAs (lincRNAs). 
DNA Methylation and Hydroxymethylation

These are covalent modifications of cytosine residues targeting the dinucleotide sequence CpG $[17,18]$. DNA is methylated by DNA methyltransferases (DNMTs), which add a methyl group to position 5 of cytosine, resulting in the formation of 5 -methylcytosine $(5-\mathrm{mC})$. The TET family of dio-oxygenase enzymes then oxidizes $5-\mathrm{mC}$ to yield 5 -hydroxymethylcytosine $(5-\mathrm{hmC})[19,20]$. The balance of $5-\mathrm{mC}$ and $5-\mathrm{hmC}$ at any given genomic region depends on the relative activity of DNMTs and TET enzymes at any given time. This balance is important because increased DNA methylation $(5-\mathrm{mC})$ is associated with gene repression, whereas hypomethylation (i.e. more $5-\mathrm{hmC}$ ) is associated with transcriptional activation [21, 22]. Basal levels of DNA methylation are maintained by DNMT1, and de novo methylation of both unmethylated and hemimethylated DNA is a function of DNMT3a and DNMT3b [17]. It is important to note that while $5-\mathrm{hmC}$ is associated with euchromatin (i.e. chromatin in the open state) and enriched in promoter regions of active genes, 5 - $\mathrm{mC}$ is more abundant in silenced genes and genomic regions containing heterochromatin (i.e. chromatin in the closed state) [21].

\section{Histone PTMs}

PTMs alter the N-terminus tails of the four histones (H2A, H2B, H3 and H4) that, wrapped around by two superhelical turns of DNA, make up the nucleosome [23, 24]. There are many PTMs such as acetylation, methylation, phosphorylation, ubiquitination and sumoylation [23]. In general, acetylation is associated with transcriptional activation, and deacetylation with gene silencing [23]. Histone methylation, on the other hand, affects gene transcription according to the amino acid residue where methylation takes place. Thus histone 3 (H3) methylation of lysine 9 and 27 (H3K9me and $\mathrm{H} 3 \mathrm{~K} 27 \mathrm{me}$ ) is usually seen associated with transcriptional quiescence, whereas $\mathrm{H} 3$ trimethylation at lysine $4(\mathrm{H} 3 \mathrm{~K} 4 \mathrm{me} 3)$ is almost invariably seen at active promoters [23]. Less is known about the role of histone phosphorylation, but available evidence suggests that it plays a role in gene activation $[23,25]$. Very interestingly, histone ubiquitination has been shown to play an essential role in regulating gene transcription. Ubiquitination of histone $2 \mathrm{~A}$ at lysine 119 is associated with gene silencing [26], and is required for the silencing activity of the Polycomb group $(\mathrm{PcG})$ repressive complex [27] (see below). Conversely, ubiquitination of $\mathrm{H} 2 \mathrm{~B}$ at lysine 120 is associated with transcriptional activation and is required for the Trithorax group (TrxG) of transcriptional activators to counteract the repressive effect of PcG on gene transcription [28] (see below).

\section{Noncoding RNAs}

Contrary to previous knowledge, it is now clear that most of the human genome is transcribed into noncoding RNAs instead of protein-encoding messenger $(\mathrm{m}) \mathrm{RNAs}$ $[29,30]$. There are two main groups of noncoding RNAs: small RNAs of 20-30 nucleotides in length and long noncoding RNAs longer than 200 nucleotides [30, 31]. 
There are three classes of small RNAs: miRNAs [29, 31], endo-small inhibitory RNAs [32] and piwiRNAs [33, 34]. All of them are involved in epigenetic silencing [29]. miRNAs have been particularly well-studied with regard to their epigenetic properties [35] and have been found to target a host of mRNAs encoding proteins required for DNA methylation and histone modifications [35]. The former include mRNAs encoding DNA methylating and demethylating enzymes (DNMTs and TET1-3, respectively). Among the latter are mRNAs encoding the enzymes responsible for trimethylation of $\mathrm{H} 3$ at lysine $27(\mathrm{EZH} 2)$ and histone deacetylation (HDAC1, 4, 6), among others [35].

Like miRNAs, long noncoding RNAs do not encode proteins, but are polyadenylated [30]. Because they are mostly produced in gene-free regions of the genome, they are known as lincRNAs. By binding to chromatin modifying complexes, lincRNAs appear to serve as scaffolds that guide these complexes to genomic regions involved in the control of gene expression $[30,36]$. The contribution of lincRNAs to epigenetic regulation is illustrated by HOTAIR, a lincRNA that directs the silencing complexes PRC2 (a subgroup of the PcG complex of transcriptional repressors, see below) and LSD1-coREST (another repressive complex) to the regulatory regions of downstream genes $[37,38]$. Because PRC2 catalyzes $\mathrm{H} 3 \mathrm{~K} 27$ trimethylation (a repressive histone mark) and LSD1-coREST demethylates H3K4me2 (an activating histone mark), HOTAIR appears to promote gene silencing. Of note, the expression of long noncoding RNAs themselves is epigenetically regulated because they can be identified in the human genome based on a unique chromatin signature termed the K4-K36 bivalency [39], which is present in transcribed genes. The K4-K36 bivalency consists of trimethylation of $\mathrm{H} 3$ at lysine 4 (H3K4me3) at the promoter region of RNA polymerase IItranscribed genes accompanied by $\mathrm{H} 3$ trimethylation at lysine 36 along the transcribed region. Because this configuration is also seen in protein-coding genes, genes encoding lincRNAs can be discerned because they do not generate a protein product.

\section{The Pivotal Role of the Polycomb Group and Trithorax Group Proteins in the Developmental Regulation of Gene Expression}

The PcG and TrxG complexes are composed of chromatin proteins with mutually antagonistic activity which allows them to play a major role in the epigenetic control of gene expression. When they act at genomic regulatory regions, the cell is provided with a mitotically heritable 'memory' that defines which genes are silenced and which are active during development $[40,41]$.

\section{The PcG Complex Represses Gene Transcription}

In mammals the $\mathrm{PcG}$ system is composed of two main repressive complexes (termed PRC1 and PRC2 for polycomb repressive complexes 1 and 2) [41]. In Drosophila there is a third complex termed PhoRC. A major component of PRC1 is the CBX 
group of proteins, characterized by the presence of a conserved chromodomain (CBX) at their amino terminus $[42,43]$. Although mammalian PRC1 contains several CBX proteins (CBX2, 4, 6, 7 and 8) [42], the composition of PRC1 from cell to cell varies because different $C B X$ genes are expressed in different cells [44]. It recently became clear that $\mathrm{CBX}$ proteins are not essential for PRC1 function because there are six different noncanonical PRC1 complexes that lack CBX proteins but are still able to repress gene expression [45].

The mammalian PRC2 complex includes four core subunits: enhancer of zeste 1 or 2 (EZH1, EZH2), suppressor of zeste (Suz12), and the WD40 domain proteins EED and P55 [26, 42]. The Drosophila PhoRC complex is composed of two proteins, Pho and its homologue Phol, which bind directly to DNA [42]. Although in mammals Yy1 performs some of the functions of these proteins, YY1 can also activate gene expression $[46,47]$, indicating that some of its actions are PcG independent.

\section{TrxG Antagonizes PcG Silencing}

TrxG proteins counteract the effect of $\mathrm{PcG}$ proteins by implementing methylation of $\mathrm{H} 3 \mathrm{~K} 4[40,48]$. In mammals, $\mathrm{H} 3 \mathrm{~K} 4$ methylation is mediated by six protein complexes termed COMPASS (complex of proteins associated to Set1) and COMPASS-like because they are related to the original yeast SET1 methyltransferase $[40,48]$. Two of these complexes (SET1A and SET1B COMPASS) contain Drosophila SET1-related proteins; two COMPASS-like complexes contain the proteins MLL1 or MLL2, which are related to Drosophila Trx (Trithorax); lastly, a third COMPASS-like complex contains either MLL3 or MLL4, both of them related to Drosophila Trr (related to Trithorax).

\section{Chromatin Posttranslational Modifications Catalyzed by Polycomb Group and Trithorax Group Protein Complexes}

Histone modifications implemented by the PcG and TrxG complexes can be divided into those associated with gene repression and those associated with gene activation. Trimethylation of $\mathrm{H} 3$ at lysine $27(\mathrm{H} 3 \mathrm{~K} 27 \mathrm{me} 3)$ is associated with transcriptional repression $[49,50]$. Conversely, $\mathrm{H} 3 \mathrm{~K} 4 \mathrm{me} 3$ is associated with gene activation [40]. The H3K27me3 mark is catalyzed by EZH2, a methyltransferase that forms part of the PcG subcomplex PRC2 [41]. Methylation of lysine 4 at $\mathrm{H} 3$ is catalyzed by enzymes of the TrxG complex [40], with different components of the complex implementing mono-, di- and trimethylation of this amino acid residue. Thus, SET1A/SET1B catalyze H3K4me3 at promoters of active genes [51], MLL2 implements this PTM at bivalent promoters $[52,53]$, i.e. those promoters that are poised for activation [54], and MLL3/MLL4 catalyze monomethylation of H3K4 at enhancer sites [51]. 


\section{Epigenetic Regulation of Puberty}

Only 2 years ago nothing was known about the role that epigenetics may play in the developmental control of neuroendocrine reproductive function. This state of affairs changed with the publication of three studies providing evidence for a contribution of epigenetics to three levels of hypothalamic control: the GnRH neuronal network, kisspeptin neurons of the AVPV and kisspeptin neurons of the ARC.

\section{The Activation of GnRH Expression during Neuronal Maturation}

Using cultured GnRH neurons from nonhuman primates, Kurien et al. [55] showed that methylation at several individual $\mathrm{CpG}$ sites (8 of 14) in a region located about 2,000 bp upstream from the GNRH transcription start site decreases in GnRH neurons at the time when GnRH expression first increases during in vitro embryonic development. These findings suggest that demethylation of specific $5^{\prime}$ flanking regions of the GNRH gene removes a repressive epigenetic influence, allowing GNRH transcription to increase during embryonic development.

\section{The Activation of Kiss1 Expression at the Time of the Preovulatory Surge of Gonadotropins}

Tomikawa et al. [56] showed that the increase in Kiss 1 expression that occurs in AVPV kisspeptin neurons as a result of a preovulatory augmentation in circulating estradiol levels is associated with increased $\mathrm{H} 3$ acetylation at the Kiss 1 promoter. In contrast, estradiol decreases $\mathrm{H} 3$ acetylation at the Kiss 1 promoter in ARC kisspeptin neurons. Estradiol also increases ERa binding to the Kiss1 promoter in the AVPV, but not the ARC. Interestingly, no changes in Kiss1 promoter DNA methylation were detected in either the AVPV or ARC, suggesting that DNA methylation may not contribute to regulating Kiss 1 promoter activity at the time of the preovulatory surge of gonadotropins. Tomikawa et al. [56] also found an estrogen-responsive enhancer in an intergenic region located $3^{\prime}$ from the Kiss 1 gene and showed that estrogen enhances chromatin looping between the Kiss1 promoter and this enhancer in AVPV, but not ARC kisspeptin neurons. Because estradiol enhances $\mathrm{H} 3$ acetylation only at the Kiss 1 promoter of AVPV kisspeptin neurons, it is likely that the AVPV-specific promoter-enhancer interaction is facilitated by the establishment of a permissive chromatin configuration by $\mathrm{H} 3$ acetylation.

\section{Activation of the Kiss 1 Gene in KNDy Neurons at the Initiation of Puberty}

In the study by Lomniczi et al. [57], we used cDNA arrays and methylation arrays to interrogate the female rat hypothalamus during the juvenile and peripubertal phases of reproductive development. The three phases examined were the early juvenile phase [postnatal day (PND) 21], late juvenile phase (PND 28), and late proestrus phase of puberty, which corresponds to the day of the first preovulatory surge of gonadotropins [58] and usually occurs between PND 32 and 36. The juvenile period is 
initiated on PND 21, and ends on PND 28-30 [58], which marks the initiation of puberty because it is at this time that a diurnal pattern of $\mathrm{LH}$ release becomes first evident in the female rat $[3,4]$.

We compared PND 28 to PND 21 animals because the increase in afternoon pulsatile LH release that occurs during the late juvenile phase of development appears to be driven by KNDy neurons of the ARC $[6,8,11]$. We examined the Kiss 1 gene as a prototype of a unique class of 'puberty-activating' genes that also includes Tac2. Both genes are expressed in the same ARC neurons, and their protein products are functionally connected, with NKB stimulating the release of kisspeptin from KNDy neurons [reviewed in 12]. The results of this study showed that Eed and Cbx7, two central components of the PcG complex, are expressed in ARC kisspeptin neurons, and that their encoded proteins are associated with the Kiss1 promoter during prepubertal development of the female rat [57]. At the end of juvenile development, methylation of the Eed and $C b x 7$ promoters increases in the ARC and this change takes place concomitantly with a reduction in the expression of both genes. As Eed and Cbx7 expression decreased, there was a reduction in association of the EED protein to the Kiss 1 promoter.

Fig. 1. Postulated epigenetic mechanisms controlling pulsatile and surge mode of $\mathrm{LH}$ release at puberty. a Diagram showing the hypothetical changes in histone marks and DNA methylation at the promoter regions of repressive and activating genes involved in the control of puberty. Also depicted is the potential temporal relationship of these changes with pubertal alterations in neuronal/ glial input to the GnRH neuronal network and the attendant modifications in pulsatile and surge mode of GnRH release. Eed, a core component of the PcG complex, is shown as an example of an upstream transcriptional repressor of puberty; Kiss1 is depicted as a prototype of downstream puberty-activating genes. Current evidence suggests that DNA methylation of repressive gene promoters, but not that of puberty-activating genes increases at puberty. $\mathbf{b}$ The epigenetic control of puberty-activating genes using the Kiss 1 gene as a prototype. According to this model the increase in pulsatile LH release that signals the initiation of puberty is brought about by the resolution of an antagonistic epigenetic mechanism of transcriptional regulation that controls the expression of Kiss 1 and perhaps other puberty-activating genes (e.g. Tac2, Nell2, TTF1, etc.) in the medial basal hypothalamus. It is postulated that during prepubertal development the transcriptional activity of these genes is repressed by silencing molecules, epitomized by the PcG complex. By catalyzing the deposition of histone PTMs associated with gene silencing (e.g. H3K27me3, blue spheres) at key regulatory regions, PcG proteins act as 'writers' of a repressive chromatin configuration. As puberty approaches, these 'writers' are evicted from promoter regions controlling puberty-activating genes, and as a result of this loss, the content of histone repressive marks is reduced. As this change takes place, a different set of writers, epitomized by the TrxG-activating complex, is recruited to these regions, resulting in the deposition of histone PTMs associated with transcriptional activation, such as $\mathrm{H} 3 \mathrm{~K} 4 \mathrm{me} 3$ (green spheres) and H3K9,14ac (red spheres). As a consequence of these changes, the association of active polymerase II (POLII) to the promoter increases. Once puberty is under way, ovarian estrogen secretion increases as a consequence of increased gonadotropin stimulation. When circulating estrogen levels reach a sustained magnitude, they activate a positive feedback mechanism that results in the first preovulatory surge of gonadotropins. Essential for the occurrence of this surge is the estrogen-dependent activation of AVPV kisspeptin neurons. The epigenetic changes underlying this activation include increased $\mathrm{H} 3$ acetylation at the Kiss 1 promoter (red spheres) and increased ERa binding (green boxes) to the Kiss1 promoter [56].

(For figure see next page.) 


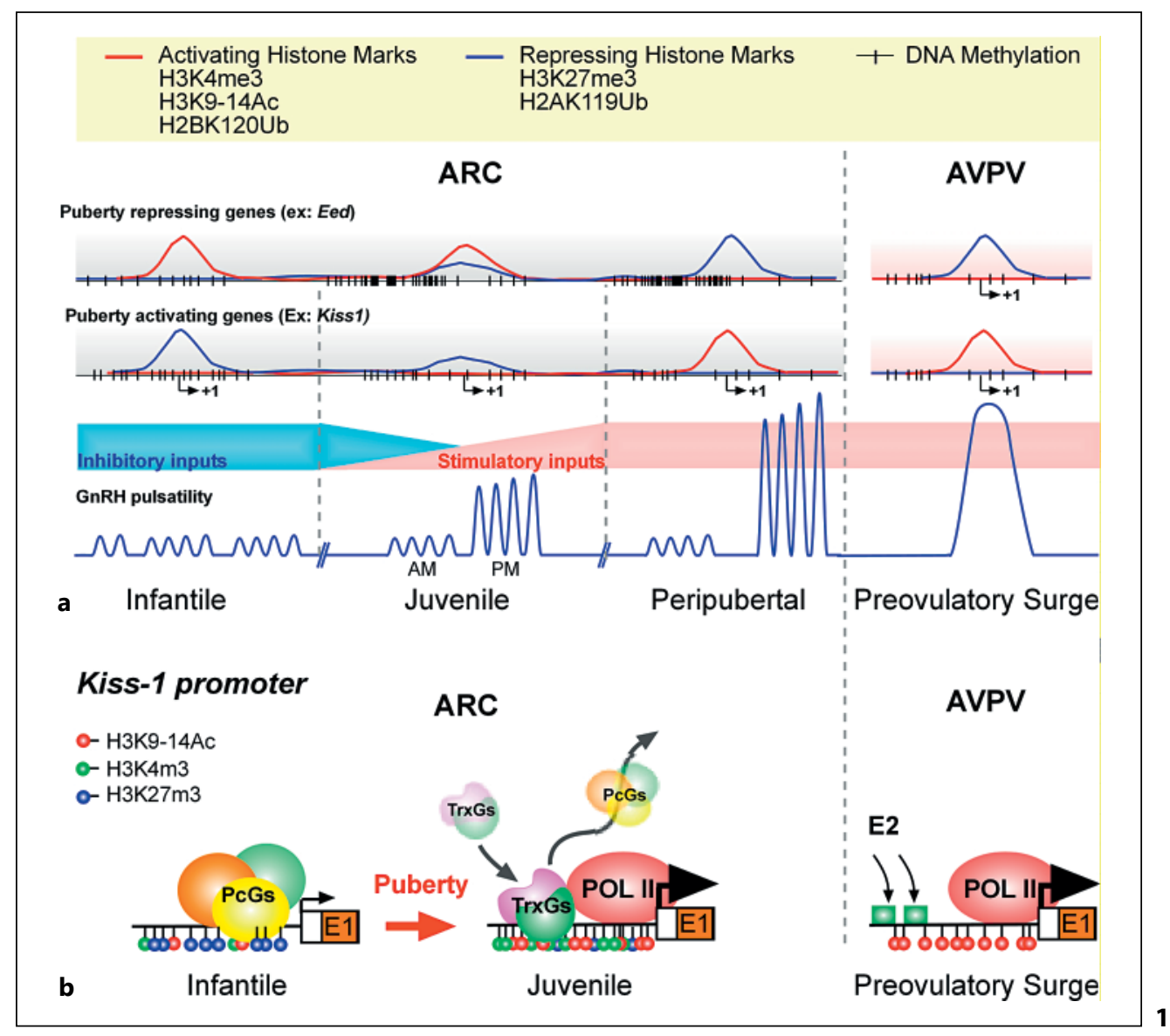

Importantly, this loss was accompanied by a change in the chromatin status of the promoter. The abundance of both acetylated $\mathrm{H} 3(\mathrm{H} 3 \mathrm{~K} 9,14 \mathrm{ac})$ and trimethylated $\mathrm{H} 3 \mathrm{~K} 4$ (H3K4me3) increased, suggesting that when puberty is initiated the chromatin configuration at the Kiss 1 promoter switches from repressive to permissive. In keeping with this notion, Kiss 1 expression also increased in the ARC at this time.

The prepubertal increase in $\mathrm{H} 3 \mathrm{~K} 4 \mathrm{me} 3$ and $\mathrm{H} 3 \mathrm{~K} 9,14 \mathrm{ac}$ abundance at the Kiss 1 promoter is revealing because it predicts the increased association of an activating complex concomitant to the loss of PcG inhibition. The TrxG complex is a candidate for this role because TrxG proteins antagonize PcG silencing by catalyzing H3K4 trimethylation and facilitating $\mathrm{H} 3$ acetylation $[41,48]$. It is possible that UTX, one of the TrxG proteins, plays a direct role in PcG eviction because of its ability to demethylate H3K27me3 [40, 59]. We speculate that by implementing these key histone PTMs, the TrxG complex may switch the epigenetic control of puberty-activating genes from repression to activation at the time of puberty. Some evidence indeed exists suggesting a physiological role of the TrxG complex in the control of puberty as inactivating mutations of $\mathrm{CHD} 7$, a chromatin remodeling protein that binds to $\mathrm{H} 3 \mathrm{~K} 4 \mathrm{me} 2$ and 
H3K4me3 via its chromodomain, results in hypothalamic hypogonadism in humans $[60,61]$. It is also possible that additional transactivating protein complexes able to 'read' the H3K4me3 mark 'written' [62] by TrxG proteins contribute to increase the transcription of puberty-activating genes. The SAGA complex is a potential candidate because it activates gene expression via binding of one of its subunits (Sfg29) to the DNA of H3K4me2/3 containing promoters [63].

The Kiss 1 promoter appears to contain a bivalent domain, i.e. a regulatory region in which both 'activating' H3K4me3 and 'repressive' H3K27me3 marks coexist, allowing the promoter to be 'poised' for activation in response to incoming inputs [54]. In this context it is interesting to note that the content of $\mathrm{H} 3 \mathrm{~K} 27 \mathrm{me} 3$ did not decrease at the same time that $\mathrm{H} 3 \mathrm{~K} 4 \mathrm{~m} 3$ abundance increased, but later on the day of the first preovulatory surge of gonadotropins [57].

The study by Lomniczi et al. [57] also addressed the issue of whether DNA methylation is an epigenetic factor involved in the control of puberty. These authors showed that the systemic administration of 5-azacytidine, an inhibitor of DNA methylation, prevented both the peripubertal decline in $C b x 7$ and Eed mRNA expression and the eviction of CBX7 and EED from the Kiss1 promoter. Notably, 5-azacytidine also impeded the association of activating histone marks to this promoter, and the increase in Kiss 1 expression that occurs at the beginning of puberty. These observations were interpreted as indicating that when the increase in DNA methylation of PcG promoters is prevented, the drop in Eed/Cbx expression is impaired and EED/CBX7 occupancy of the Kiss1 promoter fails to occur, which then reduces the accessibility of activating histone marks to the promoter. In agreement with the results of Tomikawa et al. [56], who found no alterations in DNA methylation of the Kiss1 promoter in AVPV kisspeptin neurons after estradiol exposure, we observed no changes in DNA methylation of the Kiss1 promoter in ARC kisspeptin neurons at the time of puberty, i.e. before the pubertal increase in circulating estrogen levels. Together, these results suggest that DNA methylation may not play a role in determining the changes in Kiss 1 expression that accompany the initiation of puberty in the ARC, or the preovulatory surge of gonadotropins in the AVPV.

PcG-mediated silencing appears to be an important factor restraining the premature activation of the pubertal process. When EED was delivered using a lentiviral vector to the ARC of early juvenile rats, the exogenous EED was recruited to the Kiss 1 promoter and Kiss 1 expression was reduced. This effect was evidenced by a reduced number of immunoreactive kisspeptin neurons in the ARC, a decrease in kisspeptin content per cell and a reduction in Kiss 1 mRNA levels. The biological consequences of these changes were a reduction in pulsatile $\mathrm{GnRH}$ release from the medial basal hypothalamus, delayed puberty and disruption of estrous cyclicity. Moreover, fertility was compromised as evidenced by the lower number of pups born to animals receiving EED in the ARC as compared to controls injected with the lentiviral vector expressing only green fluorescent protein [57].

It is important to also note that the decrease in PcG expression that occurs at the initiation of puberty is an estrogen-independent phenomenon, as the decrease takes 
place in the presence of low, unchanging estrogen levels, and it is not enhanced by the peripubertal increase in estrogen production. These results suggest that estrogen may not contribute to inhibit the transcription of upstream transcriptional repressors (e.g. EED), but instead has a role in transcriptional activation. Such a role is demonstrated by the ability of estradiol to (1) increase $\mathrm{H} 3$ acetylation at the Kiss 1 promoter and Kiss 1 expression in AVPV neurons [56], (2) induce demethylation of DNA and loss of $\mathrm{H} 3 \mathrm{~K} 9 \mathrm{me} 2 / 3$ from E2-target promoters $[64,65]$, (3) induce the formation of coactivating complexes containing histone acetyltransferases and histone methyltransferases, (4) induce demethylation of $\mathrm{H} 3 \mathrm{~K} 9 \mathrm{me} 2 / 3$ [65] and (5) cause rapid fluctuations in DNA methylation [64]. Altogether, these observations suggest that in most cases estrogen promotes the implementation of epigenetic marks associated with transcriptional activation instead of repression. An outstanding issue in need of resolution is the mechanism by which estradiol suppresses Kiss1 expression in ARC neurons.

\section{Posttranscriptional Regulation of Puberty}

Transcriptional repression is not the only mechanism preventing the premature acquisition of reproductive capacity. Posttranscriptional repression appears to also be important, and LIN28B was recently identified as a protein able to do just that. The involvement of $L I N 28 B$ in the regulation of human puberty was suggested by genomewide association studies showing that genomic sequence variation near the LIN $28 B$ gene in human chromosome 6(q21) is associated with earlier menarche and shorter stature in girls [66-68]. The product of $L I N 28 B$ is a cytoplasmic protein that controls gene expression posttranscriptionally mostly by decreasing the production of miRNAs of the let7 family $[69,70]$. By blocking processing of let7 precursors [71], LIN28b inhibits the formation of mature let7 miRNAs, resulting in diminished let7mediated mRNA degradation. The importance of a repressive role of LIN28 in the regulation of puberty is suggested by the ability of Lin28a overexpression to delay puberty in mice [72] and by the decrease in Lin 28 and Lin $28 b$ expression that occurs in the hypothalamus of prepubertal rats and nonhuman primates coinciding with an increase in let-7a and let-7b RNA levels [73]. These findings suggest that LIN28 may keep the pubertal process in check by downregulating miRNAs, such as the let 7 family, potentially involved in silencing genes that are inhibitory to the pubertal process.

\section{Conclusions}

The concept that the initiation and progression of female puberty is a process regulated by epigenetic mechanisms is still in its infancy. Much more remains to be done to identify the factors and unveil the pathways used by epigenetic cues to control neuroendocrine gene expression in a coordinated fashion during pubertal development. 
Likewise, little is known about the pathways conveying epigenetic information from different stimuli, such as nutrition, circadian activity and environmental toxins/endocrine disruptors to the hypothalamic cells controlling the timing of puberty. Studies addressing these issues should be conducted. A framework for such studies probably needs to be based on the assumption that epigenetic repression and activation of gene transcription is a core mechanism by which epigenetics regulates pubertal development. In addressing these major issues, one needs to be cognizant of a daunting but not unsurmountable - reality: the epigenetic code is not only highly dynamic, but also likely to differ from one cell population to another. By accepting this premise, one may also have to assume that the epigenetic code linking DNA methylation, histone PTMs and noncoding RNAs may be different not only between glial cells and neurons, but also between subsets of astroglial cells and tanycytes, as well as between neurons phenotypically differentiated to produce different neurotransmitters and neuromodulators. It appears reasonable to expect that the epigenetic landscape of neurons producing kisspeptin, NKB, glutamate, GABA, and other neurotransmitters and neuromodulators has an organization that follows basic cell biology principles. However, it must also be assumed that within each of these phenotypically differentiated cells there is a different epigenetic language at play, resulting from the dynamic interactions of a plethora of components able to respond differently to different stimuli, including not only those provided by excitatory/inhibitory neurotransmission, but also by blood-borne and environmentally derived substances.

Fortunately, a rapidly evolving technological landscape is making it feasible to address these issues in a not too distant future. A case in point is the availability of techniques for the isolation of specific neuronal and glial populations coupled with genome-wide characterization of histone and DNA methylation profiles to precisely define the epigenetic status of a given cell population at a given time in development and/or after exposure to environmental stimuli. There is little doubt that we are witnessing the advent of a new era in the quest to unravel the mystery of puberty. At the risk of being overly optimistic, we anticipate that forthcoming research will lead to the identification of specific epigenetic defects as an underlying cause of disturbed timing of puberty in humans.

\section{Lessons for Clinical Management of Pubertal Disorders}

It appears predictable that in years to come the diagnosis of pubertal disorders will still rely on traditional methods such as the evaluation of somatic changes and their progression, and measurement of circulating hormone levels, including the endocrine response to hormonal challenges, such as the pituitary response to GnRH. If the cause of the disorder is considered to be 'idiopathic', the clinician should keep in mind that not only yet-to-be-described mutations of new genes, but also alterations in epigenetic regulation, may be the culprit(s). This may be particularly important in the case 
of constitutional delayed puberty in boys and sexual precocity in girls. It must also be kept in mind that instead of affecting only one gene, epigenetic alterations may impact gene networks controlling the pubertal process. Environmental influences such as overnutrition or unbalanced diet, dysregulation of circadian activity - not an unusual feature in teenagers - and exposure to environmental pollutants are factors that require consideration. The aforementioned considerations are necessarily vague because we know little about which, how and when alterations in epigenetic regulation affect the timing of puberty. As our knowledge of this field increases, we predict that new tools will become available for the treatment of epigenetic disorders of puberty. A case in point is the recent identification of small molecules able to antagonize the repressive effects of the $\mathrm{PcG}$ complex on gene activity upon systemic administration [74]. It can be envisioned that the clinical use of such molecules will significantly expand the arsenal of tools currently available for the treatment of pubertal disorders.

\section{Acknowledgements}

This research was supported by grant IOS IOS1121691 from the National Science Foundation (NSF, USA) and 8P51OD011092 from the National Institutes of Health (NIH, USA).

\section{References}

1 Ojeda SR, Skinner MK: Puberty in the rat; in Neill JD (ed): The Physiology of Reproduction, ed 3. San Diego, Academic Press/Elsevier, 2006, pp 2061-2126.

2 Boyar R, Finkelstein J, Roffwarg H, Kapen S, Weitzman E, Hellman L: Synchronization of augmented luteinizing hormone secretion with sleep during puberty. N Engl J Med 1972;287:582-586.

3 Urbanski HF, Ojeda SR: The juvenile-peripubertal transition period in the female rat: establishment of a diurnal pattern of pulsatile luteinizing hormone secretion. Endocrinology 1985;117:644-649.

4 Urbanski HF, Ojeda SR: Gonadal-independent activation of enhanced afternoon luteinizing hormone release during pubertal development in the female rat. Endocrinology 1987;121:907-913.

5 Ojeda SR, Terasawa E: Neuroendocrine regulation of puberty; in Pfaff D, Arnold A, Etgen A, Fahrbach S, Moss R, Rubin R (eds): Hormones, Brain and Behavior. New York, Elsevier, 2002, vol 4, pp 589-659.

6 Navarro VM, Gottsch ML, Wu M, Garcia-Galiano D, Hobbs SJ, Bosch MA, Pinilla L, Clifton DK, Dearth A, Ronnekleiv OK, Braun RE, Palmiter RD, Tena-Sempere M, Alreja M, Steiner RA: Regulation of NKB pathways and their roles in the control of Kiss1 neurons in the arcuate nucleus of the male mouse. Endocrinology 2011;152:4265-4275.
7 Lehman MN, Coolen LM, Goodman RL: Minireview: kisspeptin/neurokinin B/dynorphin (KNDy) cells of the arcuate nucleus: a central node in the control of gonadotropin-releasing hormone secretion. Endocrinology 2010;151:3479-3489.

8 Wakabayashi Y, Nakada T, Murata K, Ohkura S, Mogi K, Navarro VM, Clifton DK, Mori Y, Tsukamura H, Maeda K, Steiner RA, Okamura H: Neurokinin $\mathrm{B}$ and dynorphin $\mathrm{A}$ in kisspeptin neurons of the arcuate nucleus participate in generation of periodic oscillation of neural activity driving pulsatile gonadotropin-releasing hormone secretion in the goat. J Neurosci 2010;30:3124-3132.

9 Hrabovszky E, Ciofi P, Vida B, Horvath MC, Keller E, Caraty A, Bloom SR, Ghatei MA, Dhillo WS, Liposits Z, Kallo I: The kisspeptin system of the human hypothalamus: sexual dimorphism and relationship with gonadotropin-releasing hormone and neurokinin B neurons. Eur J Neurosci 2010;31:1984-1998.

10 Hrabovszky E: Neuroanatomy of the human hypothalamic kisspeptin system. Neuroendocrinology 2014;99:33-48. 
11 Beale KE, Kinsey-Jones JS, Gardiner JV, Harrison EK, Thompson EL, Hu MH, Sleeth ML, Sam AH, Greenwood HC, McGavigan AK, Dhillo WS, Mora JM, Li XF, Franks S, Bloom SR, O’Byrne KT, Murphy KG: The physiological role of arcuate kisspeptin neurons in the control of reproductive function in female rats. Endocrinology 2014;155:1091-1098.

12 Pinilla L, Aguilar E, Dieguez C, Millar RP, TenaSempere M: Kisspeptins and reproduction: physiological roles and regulatory mechanisms. Physiol Rev 2012;92:1235-1316.

13 Grumbach MM, Styne DM: Puberty: Ontogeny, neuroendocrinology, physiology, and disorders; in Wilson JD, Foster DW (eds): Williams Textbook of Endocrinology, ed 8. Philadelphia, Saunders, 1992, pp 1139-1221.

14 Ojeda SR: The mystery of mammalian puberty: how much more do we know? Perspect Biol Med 1991;34: 365-383.

15 Seminara SB, Messager S, Chatzidaki EE, Thresher RR, Acierno JS Jr, Shagoury JK, Bo-Abbas Y, Kuohung W, Schwinof KM, Hendrick AG, Zahn D, Dixon J, Kaiser UB, Slaugenhaupt SA, Gusella JF, O’Rahilly S, Carlton MB, Crowley WF Jr, Aparicio SA, Colledge WH: The GPR54 gene as a regulator of puberty. N Engl J Med 2003;349:1614-1627.

16 de Roux N, Genin E, Carel J-C, Matsuda F, Chaussain J-L, Milgrom E: Hypogonadotropic hypogonadism due to loss of function of the KiSS1-derived peptide receptor GPR54. Proc Natl Acad Sci U S A 2003 100:10972-10976.

17 Jaenisch R, Bird A: Epigenetic regulation of gene expression: how the genome integrates intrinsic and environmental signals. Nat Genet 2003;33(suppl): 245-254.

18 Bjornsson HT, Fallin MD, Feinberg AP: An integrated epigenetic and genetic approach to common human disease. Trends Genet 2004;20:350-358.

19 Tahiliani M, Koh KP, Shen Y, Pastor WA, Bandukwala H, Brudno Y, Agarwal S, Iyer LM, Liu DR, Aravind $\mathrm{L}$, Rao A: Conversion of 5-methylcytosine to 5-hydroxymethylcytosine in mammalian DNA by MLL partner TET1. Science 2009;324:930-935.

20 Koh KP, Yabuuchi A, Rao S, Huang Y, Cunniff K, Nardone J, Laiho A, Tahiliani M, Sommer CA, Mostoslavsky G, Lahesmaa R, Orkin SH, Rodig SJ, Daley GQ, Rao A: Tet1 and Tet2 regulate 5-hydroxymethylcytosine production and cell lineage specification in mouse embryonic stem cells. Cell Stem Cell 2011; 8:200-213.

21 Ficz G, Branco MR, Seisenberger S, Santos F, Krueger F, Hore TA, Marques CJ, Andrews S, Reik W: Dynamic regulation of 5-hydroxymethylcytosine in mouse ES cells and during differentiation. Nature 2011;473:398-402.
22 Guo JU, Su Y, Zhong C, Ming GL, Song H: Emerging roles of TET proteins and 5-hydroxymethylcytosines in active DNA demethylation and beyond. Cell Cycle 2011;10:2662-2668.

23 Kouzarides T: Chromatin modifications and their function. Cell 2007;128:693-705.

24 Khorasanizadeh S: The nucleosome: from genomic organization to genomic regulation. Cell 2004;116: 259-272.

25 Crosio C, Cermakian N, Allis CD, Sassone-Corsi P: Light induces chromatin modification in cells of the mammalian circadian clock. Nat Neurosci 2000;3: 1241-1247.

26 Di Croce L, Helin K: Transcriptional regulation by Polycomb group proteins. Nat Struct Mol Biol 2013; 20:1147-1155.

$27 \mathrm{Wu}$ X, Johansen JV, Helin K: Fbxl10/Kdm2b recruits polycomb repressive complex 1 to $\mathrm{CpG}$ islands and regulates H2A ubiquitylation. Mol Cell 2013;49: 1134-1146.

28 Kim J, Kim JA, McGinty RK, Nguyen UT, Muir TW, Allis CD, Roeder RG: The n-SET domain of Set1 regulates H2B ubiquitylation-dependent H3K4 methylation. Mol Cell 2013;49:1121-1133.

29 Huang B, Jiang C, Zhang R: Epigenetics: the language of the cell? Epigenomics 2014;6:73-88.

30 Batista PJ, Chang HY: Long noncoding RNAs: cellular address codes in development and disease. Cell 2013;152:1298-1307.

31 Filipowicz W, Bhattacharyya SN, Sonenberg N: Mechanisms of post-transcriptional regulation by microRNAs: are the answers in sight? Nat Rev Genet 2008;9:102-114.

32 Okamura K, Chung WJ, Ruby JG, Guo H, Bartel DP, Lai EC: The Drosophila hairpin RNA pathway generates endogenous short interfering RNAs. Nature 2008;453:803-806

33 Kim VN: Small RNAs just got bigger: Piwi-interacting RNAs (piRNAs) in mammalian testes. Genes Dev 2006;20:1993-1997.

34 Girard A, Sachidanandam R, Hannon GJ, Carmell MA: A germline-specific class of small RNAs binds mammalian Piwi proteins. Nature 2006;442:199_ 202.

35 Gruber AJ, Zavolan M: Modulation of epigenetic regulators and cell fate decisions by miRNAs. Epigenomics 2013;5:671-683.

36 Spitale RC, Tsai MC, Chang HY: RNA templating the epigenome: long noncoding RNAs as molecular scaffolds. Epigenetics 2011;6:539-543.

37 Chu C, Qu K, Zhong FL, Artandi SE, Chang HY: Genomic maps of long noncoding RNA occupancy reveal principles of RNA-chromatin interactions. Mol Cell 2011;44:667-678. 
38 Rinn JL, Kertesz M, Wang JK, Squazzo SL, Xu X, Brugmann SA, Goodnough LH, Helms JA, Farnham PJ, Segal E, Chang HY: Functional demarcation of active and silent chromatin domains in human HOX loci by noncoding RNAs. Cell 2007;129:1311-1323.

39 Guttman M, Amit I, Garber M, French C, Lin MF, Feldser D, Huarte M, Zuk O, Carey BW, Cassady JP, Cabili MN, Jaenisch R, Mikkelsen TS, Jacks T, Hacohen N, Bernstein BE, Kellis M, Regev A, Rinn JL, Lander ES: Chromatin signature reveals over a thousand highly conserved large non-coding RNAs in mammals. Nature 2009;458:223-227.

40 Schuettengruber B, Martinez AM, Iovino N, Cavalli G: Trithorax group proteins: switching genes on and keeping them active. Nat Rev Mol Cell Biol 2011;12: 799-814.

41 Simon JA, Kingston RE: Mechanisms of Polycomb gene silencing: knowns and unknowns. Nat Rev Mol Cell Biol 2009;10:697-708.

42 Schwartz YB, Pirrotta V: Polycomb silencing mechanisms and the management of genomic programmes. Nat Rev Genet 2007;8:9-22.

43 Köhler C, Villar CB: Programming of gene expression by Polycomb group proteins. Trends Cell Biol 2008;18:236-243.

44 Otte AP, Kwaks TH: Gene repression by Polycomb group protein complexes: a distinct complex for every occasion? Curr Opin Genet Dev 2003;13:448454.

45 Gao Z, Zhang J, Bonasio R, Strino F, Sawai A, Parisi F, Kluger Y, Reinberg D: PCGF homologs, CBX proteins, and RYBP define functionally distinct PRC1 family complexes. Mol Cell 2012;45:344-356.

46 Shrivastava A, Calame K: An analysis of genes regulated by the multi-functional transcriptional regulator Yin Yang-1. Nucleic Acids Res 1994;22:51515155.

47 Thomas MJ, Seto E: Unlocking the mechanisms of transcription factor YY1: are chromatin modifying enzymes the key? Gene 1999;236:197-208.

48 Shilatifard A: The COMPASS family of histone H3K4 methylases: mechanisms of regulation in development and disease pathogenesis. Annu Rev Biochem 2012;81:65-95.

49 Wang Z, Zang C, Rosenfeld JA, Schones DE, Barski A, Cuddapah S, Cui K, Roh TY, Peng W, Zhang MQ, Zhao K: Combinatorial patterns of histone acetylations and methylations in the human genome. Nat Genet 2008;40:897-903.

50 Lee BM, Mahadevan LC: Stability of histone modifications across mammalian genomes: implications for 'epigenetic' marking. J Cell Biochem 2009;108: $22-34$.
51 Hu D, Gao X, Morgan MA, Herz HM, Smith ER, Shilatifard A: The MLL3/MLL4 branches of the COMPASS family function as major histone H3K4 monomethylases at enhancers. Mol Cell Biol 2013; 33:4745-4754.

52 Denissov S, Hofemeister H, Marks H, Kranz A, Ciotta G, Singh S, Anastassiadis K, Stunnenberg HG, Stewart AF: Mll2 is required for H3K4 trimethylation on bivalent promoters in embryonic stem cells, whereas Mll1 is redundant. Development 2014;141: 526-537.

53 Wu M, Wang PF, Lee JS, Martin-Brown S, Florens L, Washburn M, Shilatifard A: Molecular regulation of H3K4 trimethylation by Wdr82, a component of human Set1/COMPASS. Mol Cell Biol 2008;28:73377344 .

54 Bernstein BE, Mikkelsen TS, Xie X, Kamal M, Huebert DJ, Cuff J, Fry B, Meissner A, Wernig M, Plath K, Jaenisch R, Wagschal A, Feil R, Schreiber SL, Lander ES: A bivalent chromatin structure marks key developmental genes in embryonic stem cells. Cell 2006;125:315-326.

55 Kurian JR, Keen KL, Terasawa E: Epigenetic changes coincide with in vitro primate GnRH neuronal maturation. Endocrinology 2010;151:5359-5368.

56 Tomikawa J, Uenoyama Y, Ozawa M, Fukanuma T, Takase K, Goto T, Abe H, Ieda N, Minabe S, Deura C, Inoue N, Sanbo M, Tomita K, Hirabayashi M, Tanaka S, Imamura T, Okamura H, Maeda K, Tsukamura $\mathrm{H}$ : Epigenetic regulation of Kiss1 gene expression mediating estrogen-positive feedback action in the mouse brain. Proc Natl Acad Sci U S A 2012;109:E1294-E1301.

57 Lomniczi A, Loche A, Castellano JM, Ronnekleiv OK, Bosh M, Kaidar G, Knoll JG, Wright H, Pfeifer GP, Ojeda SR: Epigenetic control of female puberty. Nat Neurosci 2013;16:281-289.

58 Ojeda SR, Urbanski HF: Puberty in the rat; in Knobil E, Neill JD (eds): The Physiology of Reproduction, ed 2. New York, Raven Press, 1994, vol 2, pp 363409.

59 Herz HM, Mohan M, Garruss AS, Liang K, Takahashi YH, Mickey K, Voets O, Verrijzer CP, Shilatifard A: Enhancer-associated H3K4 monomethylation by Trithorax-related, the Drosophila homolog of mammalian Mll3/Mll4. Genes Dev 2012;26:26042620.

60 Bianco SD, Kaiser UB: The genetic and molecular basis of idiopathic hypogonadotropic hypogonadism. Nat Rev Endocrinol 2009;5:569-576.

61 Kim HG, Kurth I, Lan F, Meliciani I, Wenzel W, Eom SH, Kang GB, Rosenberger G, Tekin M, Ozata M, Bick DP, Sherins RJ, Walker SL, Shi Y, Gusella JF, Layman LC: Mutations in CHD7, encoding a chromatin-remodeling protein, cause idiopathic hypogonadotropic hypogonadism and Kallmann syndrome. Am J Hum Genet 2008;83:511-519. 
62 Borrelli E, Nestler EJ, Allis CD, Sassone-Corsi P: Decoding the epigenetic language of neuronal plasticity. Neuron 2008;60:961-974.

63 Vermeulen M, Eberl HC, Matarese F, Marks H, Denissov S, Butter F, Lee KK, Olsen JV, Hyman AA, Stunnenberg HG, Mann M: Quantitative interaction proteomics and genome-wide profiling of epigenetic histone marks and their readers. Cell 2010;142:967980

64 Metivier R, Gallais R, Tiffoche C, Le PC, Jurkowska RZ, Carmouche RP, Ibberson D, Barath P, Demay F, Reid G, Benes V, Jeltsch A, Gannon F, Salbert G: Cyclical DNA methylation of a transcriptionally active promoter. Nature 2008;452:45-50.

65 Perillo B, Ombra MN, Bertoni A, Cuozzo C, Sacchetti S, Sasso A, Chiariotti L, Malorni A, Abbondanza C, Avvedimento EV: DNA oxidation as triggered by H3K9me2 demethylation drives estrogen-induced gene expression. Science 2008;319:202-206.

66 Perry JR, Stolk L, Franceschini N, Lunetta KL, Zhai G, McArdle PF, Smith AV, Aspelund T, Bandinelli S, Boerwinkle E, Cherkas L, Eiriksdottir G, Estrada K, Ferrucci L, Folsom AR, Garcia M, Gudnason V, Hofman A, Karasik D, Kiel DP, Launer LJ, van MJ, Nalls MA, Rivadeneira F, Shuldiner AR, Singleton A, Soranzo N, Tanaka T, Visser JA, Weedon MN, Wilson SG, Zhuang V, Streeten EA, Harris TB, Murray A, Spector TD, Demerath EW, Uitterlinden AG, Murabito JM: Meta-analysis of genome-wide association data identifies two loci influencing age at menarche. Nat Genet 2009;41:648-650.

67 Sulem P, Gudbjartsson DF, Rafnar T, Holm H, Olafsdottir EJ, Olafsdottir GH, Jonsson T, Alexandersen P, Feenstra B, Boyd HA, Aben KK, Verbeek AL, Roeleveld N, Jonasdottir A, Styrkarsdottir U, Steinthorsdottir V, Karason A, Stacey SN, Gudmundsson J, Jakobsdottir M, Thorleifsson G, Hardarson G, Gulcher J, Kong A, Kiemeney LA, Melbye M, Christiansen C, Tryggvadottir L, Thorsteinsdottir U, Stefansson K: Genome-wide association study identifies sequence variants on 6q21 associated with age at menarche. Nat Genet 2009;41:734-738.
68 Ong KK, Elks CE, Li S, Zhao JH, Luan J, Andersen LB, Bingham SA, Brage S, Smith GD, Ekelund U, Gillson CJ, Glaser B, Golding J, Hardy R, Khaw KT, Kuh D, Luben R, Marcus M, McGeehin MA, Ness AR, Northstone K, Ring SM, Rubin C, Sims MA, Song K, Strachan DP, Vollenweider P, Waeber G, Waterworth DM, Wong A, Deloukas P, Barroso I, Mooser V, Loos RJ, Wareham NJ: Genetic variation in LIN28B is associated with the timing of puberty. Nat Genet 2009;41:729-733.

69 Moss EG, Lee RC, Ambros V: The cold shock domain protein LIN-28 controls developmental timing in C. elegans and is regulated by the lin- 4 RNA. Cell 1997;88:637-646.

70 Viswanathan SR, Powers JT, Einhorn W, Hoshida Y, $\mathrm{Ng}$ TL, Toffanin S, O’Sullivan M, Lu J, Phillips LA, Lockhart VL, Shah SP, Tanwar PS, Mermel CH, Beroukhim R, Azam M, Teixeira J, Meyerson M, Hughes TP, Llovet JM, Radich J, Mullighan CG, Golub TR, Sorensen PH, Daley GQ: Lin28 promotes transformation and is associated with advanced human malignancies. Nat Genet 2009;41:843-848.

71 Viswanathan SR, Daley GQ, Gregory RI: Selective blockade of microRNA processing by Lin 28 . Science 2008;320:97-100.

72 Zhu H, Shah S, Shyh-Chang N, Shinoda G, Einhorn WS, Viswanathan SR, Takeuchi A, Grasemann C, Rinn JL, Lopez MF, Hirschhorn JN, Palmert MR, Daley GQ: Lin28a transgenic mice manifest size and puberty phenotypes identified in human genetic association studies. Nat Genet 2010;42:626-630.

73 Sangiao-Alvarellos S, Manfredi-Lozano M, Ruiz-Pino F, Navarro V, Sanchez-Garrido MA, Leon S, Dieguez C, Cordido F, Matagne V, Dissen GA, Ojeda SR, Pinilla L, Tena-Sempere M: Changes in hypothalamic expression of the Lin28/let-7 system and related microRNAs during postnatal maturation and after experimental manipulations of puberty. Endocrinology 2013;154:942-955.

74 Knutson SK, Wigle TJ, Warholic NM, Sneeringer CJ, Allain CJ, Klaus CR, Sacks JD, Raimondi A, Majer CR, Song J, Scott MP, Jin L, Smith JJ, Olhava EJ, Chesworth R, Moyer MP, Richon VM, Copeland RA, Keilhack H, Pollock RM, Kuntz KW: A selective inhibitor of EZH2 blocks H3K27 methylation and kills mutant lymphoma cells. Nat Chem Biol 2012;8: 890-896.

\author{
Alejandro Lomniczi and Sergio R. Ojeda \\ Division of Neuroscience, Oregon National Primate Research Center \\ 505 NW 185th Avenue \\ Beaverton, OR 97006 (USA) \\ E-Mail lomniczi@ohsu.edu and ojedas@ohsu.edu
}

